\title{
The Near-Death Experience and the Taoism of Chuang Tzu
}

\author{
E. J. Hermann \\ University of Connecticut
}

\begin{abstract}
This paper compares excerpts from Chuang Tzu's writings and the descriptions of near-death experiencers (NDErs). Similarities between the beliefs of NDErs and those of Taoist patriarch Chuang Tzu suggest that NDErs have experienced a kind of awakening that leads them to reject conventional attitudes toward life and death.
\end{abstract}

Chuang Tzu (369 B.C.?-286 B.C.?), or Master Chuang, was a significant interpreter of Taoism best known for his work Chuang Tzu. The only certain facts known about him are from the Shih chi or Records of the Historian by Ssu-ma Ch'ien (145 B.C.?-89 B.C.?), which stated that Chuang Tzu's personal name was Chou, that he lived in a place called Meng, and that he wrote a fictional work of 100,000 words or more. Ssu-ma Ch'ien also wrote that Chuang-Tzu's teachings were drawn primarily from the sayings of Lao Tzu, but that his perspective was much broader.

The present version of the work entitled Chuang Tzu (Watson, 1964) consists of 33 sections, which are divided into three groups, called the inner chapters, the outer chapters, and miscellaneous chapters. It is generally agreed that the inner chapters are the best representations of the entire Chuang Tzu.

The essence of Taoism is freedom. Taoists believe that in order to gain freedom, the individual must not resist the way of nature. To

E. J. Hermann is with the Department of Psychology at the University of Connecticut. Requests for reprints should be addressed to Mr. Hermann at 381 Guerdat Road, Torrington, CT 06790. 
Chuang Tzu, man is small and insignificant, and knows virtually nothing about anything. Chuang Tzu casts a critical eye on those who believe they in fact know some truth, or some right way. He believes that it is conventions and labels of right and wrong that cause us to suffer, and that when we give up this constant labeling of right and wrong, good and bad, then we can be free from suffering, since we no longer regard our present situation as any better or worse than any other situation. This giving up of one's own self-centered way is called $w u-w e i$, in which Taoists proclaim that we become the Way itself, and our actions are as spontaneous and free-flowing as the natural world.

This paper compares the attitudes and beliefs of near-death experiencers (NDErs) to the Taoist philosophy of Chuang Tzu. The purpose is to demonstrate that NDErs tend to approach life and death in a way that is compatible with the teachings of Chuang Tzu.

I undertake this task with considerable caution, because of the difficulty in relating mystical and spiritual experience. Chuang Tzu said "to organize is to destroy," and he probably would not approve this effort to dissect his work. I have quoted him extensively to show Chuang Tzu's humor and to avoid distortion.

I chose Chuang Tzu in particular because his teachings seem to be "addressed to the spiritual elite" (Watson, 1964, p. 8), which I believe includes core NDErs. Furthermore, Chuang Tzu continually stressed the futility of words, conventions, and dogma; Burton Watson noted (1964, p. 5): "Chuang Tzu uses throughout his writings that deadliest of weapons against all that is pompous, staid, and holy: humor." NDErs, when describing their experiences and views of life, also express a concern with spirituality, and not with religious dogma and its endless distinctions.

To begin, I would like to make a comparison between the core experience of NDErs and Chuang Tzu's descriptions of the Way. Chuang Tzu fully realized the problem of explaining the Way, as Watson explains (1964, p. 7):

Like all mystics, Chuang Tzu insists that language is in the end grievously inadequate to describe the true Way, or the wonderful freedom of the man who has realized his identity with it. Again and again, he cautions that he is giving only a "rough" or "reckless" description of highly poetic and paradoxical language that in fact conveys little more than the essential ineffability of such a state of being.

Compare this to Kenneth Ring's warning in regard to core NDEs and spiritual awakening (Ring, 1984, p. 51): 
First, you must be aware-and some of the respondents I will be quoting make this point explicitly - that there is absolutely no way in which ordinary human language can communicate the essence of these deep NDEs. No verbal or written account can possibly do more than hint at the experience; never can one describe it adequately.

What follows is a comparison between NDE accounts and Chuang Tzu's description of the Way. It is hard to distinguish between the two. The following are two NDErs' accounts of the core experience:

Everything that occurred to me while I was in this state of conscious-
ness was vastly beyond anything I had ever experienced and yet at the
same time it was familiar-as if I had always known of its existence.
Even now when I try to describe something so beautiful I am mute
with awe. There are no words in any language to describe such
grandeur. Even the great literary works by men and women fortunate
enough to have experienced this blissful state only paint a shadow of
its glory. (Ring, 1984, pp. 64-65)

There was a transmission of a higher power, knowledge, understanding, and the "oneness of everything" through gazing upon the light. (Ring, 1984, p. 88)

The above two accounts indicate that in the deepest part of the core NDE, one feels beyond everything, but at the same time one with everything. Chuang Tzu tried to achieve the same effect through this passage, in which he expressed both the ineffability and this "oneness with everything":

Master Tung-kuo asked Chuang Tzu, "This thing called the Waywhere does it exist?"

Chuang Tzu said, "There is no place it doesn't exist."

"Come," said Master Tung-kuo, "you must be more specific!"

"It is in the ant."

"As low a thing as that?"

"It is in the panic grass."

"But that's lower still!"

"It is in the tiles and shards."

"How can it be so low?"

"It is in the piss and dung." (Watson, 1964. p. 16)

Here are two more NDE accounts that express the ineffability, as almost all accounts do, and also focus on the timelessness of the core experience:

It's difficult to describe; as a matter of fact, it's impossible to describe. Verbally, it cannot be expressed. It's something which becomes you 
and you become it. I could say, "I was peace; I was love." I was the brightness, it was part of me. . . . You just know. You're all-knowing and everything is a part of you-it's-it's just so beautiful. It was eternity. It's like I was always there and I will always be there, and that my existence on earth was just a brief instant. (Ring, 1984, p. 54)

It was timeless. I was just an infinite being in perfection. And love and safety and security and knowing that nothing could happen to you and you're home forever. That you're safe forever. And that everybody else was. (Ring, 1984. p. 62)

Compare this with Chuang Tzu's description of timelessness as he attempted to convey something about the Way:

It is its own source, its own root. Before Heaven and earth existed it was there, firm from ancient times. It gave spirituality to the spirits of God; it gave birth to Heaven and to earth. It exists beyond the highest point, and yet you cannot call it lofty; it exists beneath the limit of the six directions, and yet you cannot call it deep. It was born before Heaven and earth, and yet you cannot say it has been there for long; it is earlier than the earliest of time, and yet you cannot call it old. (Watson, 1964, p. 77)

NDErs express the great love and acceptance they experienced during the core experience, the infiniteness and sense of eternity:

I felt light-good-happy-joy-at ease. Forever-eternal love. Time meant nothing. Just being. Love. Pure love. Love. The Light was yellow. It was in, around, and through everything. . . . It is God made visible. In, around, and through everything. One who has not experienced it cannot know its feeling. One who has experienced it can never forget it, yearns for its perfection, and longs for the embodiment of It. (Ring, 1984, pp. 55-56)

Compare this with two quotes from Chuang Tzu:

"I have heard the way!"

"Can the Way be learned?"

"Goodness, how could that be? ... This is the kind of thing it is: there's nothing it doesn't send off, nothing it doesn't welcome, nothing it doesn't destroy, nothing it doesn't complete. It's name is Peace-inStrife. After the strife, it attains completion." (Watson, 1964, pp. 78-80)

Pour into it and it is never full, dip from it and it never runs dry, and yet it does not know where the supply comes from. This is called the Shaded Light (or precious light). (Watson, 1964, p. 40) 
Notice that there "is nothing it doesn't welcome or destroy," and the reference to light.

Chuang Tzu mentioned a "teacher" who passes judgment without being righteous:

This Teacher of mine, this Teacher of mine-he passes judgment on the ten thousand things but he doesn't think himself righteous; his bounty extends to ten thousand generations but he doesn't think himself benevolent. (Watson, 1964, p. 86)

Compare the above passage to two typical accounts of an NDE life review, noting that both NDErs make references to a learning, forgiving quality much like Chuang Tzu's benevolent Teacher's:

His attitude when we came to these scenes (selfish ones) was just that I had been learning, even then. (Moody, 1975, p. 98)

Instantly my entire life was laid bare and open to this wonderful presence, "GOD." I felt inside my being his forgiveness for the things in my life I was ashamed of, as though they were not of great importance. (Ring, 1984, p. 67)

Next I would like to address the problems NDErs face when they attempt to relate their experiences for the first time. Like NDErs, Chuang Tzu realized the problems in describing spiritual and mystical experiences. The spiritual realm that Chuang Tzu and NDErs see is not immediately accessible to most people, who therefore cannot understand it. Chuang Tzu illustrated this point with a dialogue between a great river and Jo of the North Sea:

Jo of the North Sea said, "You can't discuss the ocean with a well frog-he's limited by the space he lives in. You can't discuss ice with a summer insect-he's bound to a single season. You can't discuss the Way with a cramped scholar-he's shackled by his doctrines. Now you have come out beyond your banks and borders and have seen the great sea-so you realize your own pettiness. From now on it will be possible to talk to you about the Great Principle." (Watson, 1964, p. 97)

Here is what some NDErs told Raymond Moody about trying to relate their experiences:

It was very interesting. It's just that I don't like telling people about it. People just kind of look at you like you're crazy. (Moody, 1975. p. 85)

You learn very quickly that people don't take to this as easily as you would like for them to. You simply don't jump up on a little soapbox and go around telling everyone these things. (Moody, 1975. p. 87) 
Moody explained that many NDErs don't even bother to try to tell others because the experience is "beyond human language and human modes of perception and existence," much as discussing "ice with a summer insect" would be, as Chuang Tzu wrote. Here is one more account from Chuang Tzu on the same topic; it involves the reaction of a fictional little quail to the superior flight of the great Peng bird, who soars to ninety thousand li:

The little quail laughs at him, saying, "Where does he think he's going? I give a great leap and fly up, but I never get more than ten or twelve yards before I come down fluttering among the weeds and brambles. And that's the best kind of flying anyway! Where does he think he's going?" Such is the difference between big and little. (Watson, 1964, p. 25)

Compare this reaction to one that an NDEr received from two priests and a nurse:

Father X and Father Y, and they kind of shushed me, just like, you
know, don't talk about it, just don't talk about it. And when I men-
tioned it to one of the nurses at the hospital, her reaction was very
negative. She said ... "Don't even talk about it, we don't want to hear
about it." So everyone I talked to at the hospital seemed almost afraid
to discuss it. (Ring, 1984, p. 95)

The similarity of reactions is clear: those who haven't seen this new state can't comprehend it. Furthermore, those who are oblivious to this "other side" try to bring those that have experienced it back down to the same level.

I would like now to move on to a comparison between NDErs and Chuang Tzu on the topic of life after death. Moody wrote that NDErs are no longer afraid of death, but liken it to a transformation from one state to another. Furthermore this new state is very pleasurable and desirable. Fear of death becomes mere ignorance to those who experience the dropping away of the physical body.

Persons who have "died" choose analogies which portray death as a transition from one state to another, or as an entry into a higher state of consciousness or of being. One woman whose deceased relatives were there to greet her at her death compared death to a "homecoming." Others have likened it to other psychologically positive states, for example, to awakening, to graduating, and to escape from jail. (Moody, 1975, pp. 96-97) 
As before, the similarity between NDErs and Chuang Tzu's view of life and death is obvious in the following passage. Note the similarity of NDErs' "homecomings" to Chuang Tzu's concept that hating death is like forgetting the way back home:

\begin{abstract}
How do I know that living life is not a delusion? How do I know that in hating death I am not like a man who, having left home in his youth, has forgotten the way back?

Lady $\mathrm{Li}$ was the daughter of the border guard of $\mathrm{Ai}$. When she was first taken captive and brought to the state of Chin, she wept until her tears drenched the collar of her robe. But later, when she went to live in the palace of the ruler, shared his couch with him, and ate the delicious meats of his table, she wondered why she had ever wept. How do I know that the dead do not wonder why they ever longed for life? (Watson, 1964, p. 46)
\end{abstract}

Some NDErs make the analogy that life is an imprisonment and that death is a release:

Life is like imprisonment. In this state, we just can't understand what prisons these bodies are. Death is such a release-like an escape from prison. That's the best thing I can think of to compare it to. (Moody, 1975, p. 97)

Chuang Tzu wrote that life and death are "the same story"; when we realize this fact, we can be released from our "handcuffs and fetters":

Lao Tzu said, "Why don't you just make him see that life and death are the same story, that acceptable and unacceptable are on a single string? Wouldn't it be well to free him from his handcuffs and fetters?" (Watson, 1964, p. 68)

Compare the following two excerpts, the first from an NDEr, the second from Chuang Tzu. Here the two explain that we should "go along" with life and accept things the way they are, which is the essence of Taoism, and not resist or be afraid of death.

Now, I am not afraid to die. It's not that I have a death wish, or want to die right now. I don't want to be living over there on the other side now, because I'm supposed to be living here. The reason why I'm not afraid to die, though, is that I know where I'm going when I leave here, because I've been there before. (Moody, 1975, pp. 95-96)

The Great Clod burdens me with form, labors me with life, eases me in old age and rests me in death. So if I think well of my life, for the same 
reason I must think well of my death. When a skilled smith is casting metal, if the metal should leap up and say, "I insist upon being made into a Mo-yeh [famous sword] he would surely regard it as very inauspicious metal indeed. Now, having had the audacity to take on human form once, if I should say, "I don't want to be anything but a man! Nothing but a man!", the Creator would surely regard me as a most inauspicious sort of person. So now I think of heaven and earth as a great furnace, and the creator as a skilled smith. Where could he send me that would not be all right? I will go off to sleep peacefully, and then with a start I will wake up. (Watson, 1964, pp. 80-82)

The next comparisons I would like to make use the reactions of an NDEr towards death in her family.

The nurse was devastated. She knew Tari was dead and I didn't. "Oh, God!" she wailed. "Your doctor should have been here by now! I'm not supposed to tell you, but I can't let you go on believing Tari is alive. She died early this morning."

"Are you OK?" she asked.

"Yes," I told her much too calmly under the circumstances. In the weeks following, I felt no grief of my own loss, but I felt sorry for my friends and relatives who didn't know where Tari was, and couldn't believe-really believe-that my "experience" was anything more than a vivid dream.

I still don't know who he was, nor do I care! I know he exists at least.

Well, I soon realized that my acceptance back into this world depended upon "pretending" to forget, and "pretending" to grieve the loss of my baby. So I did this for everybody else's sake. (Ring, 1984, pp. 80-81)

This NDEr took the death of her child calmly, and felt no grief for her own loss, but pretended to grieve the loss of her baby "for everybody else's sake." In the passage below, Yen Hui has just lost his mother, but like the NDEr he wails not for his own loss but because others expect him to:

Yen Hui said to Confucius, "When Meng-sun Ts'ai's mother died, he wailed without shedding any tears, he did not grieve in his heart, and he conducted the funeral without any look of sorrow. He fell down on these three counts, and yet he is known all over the state of Lu for the excellent way he managed the funeral. Is it really possible to gain such a reputation when there are no facts to support it? I find it very peculiar indeed!"'”

Confucius said, "Meng-sun did all there was to do. He was advanced beyond ordinary understanding and he would have simplified things even more, but that wasn't practical. However, there is still a lot that he simplified. Meng-sun doesn't know why he lives and doesn't know 
why he dies. He doesn't know why he should go ahead; he doesn't know why he should fall behind. In the process of change, he has become a thing [among other things], and he is merely waiting for some other change that he doesn't yet know about. Moreover, when he is changing, how does he know that he is really changing? And when he is not changing, how does he know that he hasn't already changed? You and I, now - we are dreaming and haven't waked up yet. But in his case, though something may startle his body, it won't injure his mind; his emotions will suffer no death. Meng-sun alone has waked up. Men wail and so he wails, too-that's the reason he acts like this. (Watson, 1964, pp. 84-85)

When the husband and son of the NDEr quoted above died also, she was convinced that they too survived death:

My beloved husband died in my arms at home 16 years later. My firstborn son lived to be 25 and was killed in a car accident (instantly-no time for pain or suffering) seven years after the death of my husband.

My grief was softened and shortened each time. People said, "She's in shock now, she'll grieve more later." Later they said, "She must be a very strong person to live through what she's had to live through so calmly." Neither statement was true. It feels good to tell the truth to someone. They aren't dead. They are all alive, busy and waiting for me. Our separation is only temporary and very short, compared to all of eternity. (Ring, 1984, p. 82)

Chuang Tzu took things a bit further and started to sing and pound on a tub after his wife died. Hui Tzu, a student of Chuang Tzu, questioned him on this behavior:

Chuang Tzu's wife died. When Hui Tzu went to convey his condolences, he found Chuang Tzu sitting with his legs sprawled out, pounding on a tub and singing. "You lived with her, she brought up your children and grew old," said Hui Tzu. "It should be enough simply not to weep at her death. But pounding on a tub and singingthis is going too far, isn't it?"

Chuang Tzu said, "You're wrong. When she first died, do you think I didn't grieve like anyone else? But I looked back to her beginning and the time before she was born. Not only the time before she was born, but the time before she had a body. Not only the time before she had a body, but the time before she had a spirit. In the midst of the jumble of wonder and mystery a change took place and she had a spirit. Another change and she had a body. Another change and she was born. Now there's been another change and she's dead. It's just like the progression of the four seasons, spring, summer, fall, winter.

"Now she's going to lie down peacefully in a vast room. If I were to follow after her bawling and sobbing, it would show that I don't understand anything about fate. So I stopped." (Watson, 1964, p. 113) 
My last comparison on the subject of death concerns an NDEr who was sent back to earth against his wishes:

The next thing is that in thirty years, I experienced the worst feeling I ever had. The most depressed, the most severe anxiety l've ever had was at the moment I realized I must return to this earth. That is the greatest depths of depression I personally have ever had since that time or before. It was so devastatin' that I cannot think of anything bad that has ever happened to me and put it in the same parametersthe distance is a million miles. I did not want to come back. And now that I'm back, I'm absolutely assured of the fact that I did not want to come back.... This [earth] is a wonderful place to live if you don't know anywhere else. I know somewhere else. (Ring, 1984. p. 91)

This NDEr has realized "somewhere else" beyond the realm of earth. The following passage from Chuang Tzu describes a skull that lives "somewhere else." Notice how similar the reactions of the skull and the NDEr are when they consider returning to earth from death:

When Chuang Tzu went to Ch'u, he saw an old skull, all dry and parched. He poked it with his carriage whip and then asked, "Sir, were you greedy for life and forgetful of reason, and so came to this? Was your state overthrown and did you bow beneath the ax and so came to this? Did you do some evil deed and were you ashamed to bring disgrace upon your parents and family, and so came to this? Was it through the pangs of cold and hunger that you came to this? Or did your springs and autumns pile up until they brought you to this?"

When he had finished speaking, he dragged the skull over and, using it for a pillow, lay down to sleep.

In the middle of the night, the skull came to him in a dream and said, "You chatter like a rhetorician and all your words betray the entanglements of a living man. The dead know nothing of these! Would you like to hear a lecture on the dead?"

"Indeed," said Chuang Tzu.

The skull said, "Among the dead there are no rulers above, no subjects below, and no chores of the four seasons. With nothing to do, our springs and autumns are as endless as heaven and earth. A king facing south on his throne could have no more happiness than this!"

Chuang Tzu couldn't believe this and said, "If I got the Arbiter of Fate to give you a body again, make you some bones and flesh, return you to your parents and family and your old home and friends, you would want that, wouldn't you?"

The skull frowned severely, wrinkling up its brow. "Why would I throw away more happiness than that of a king on a throne and take on the troubles of a human being again?" it said. (Watson, 1964, pp. 113-115) 
Both the skull and the NDEr were more happy dead than they ever were on earth, and for that reason did not want to come back. The NDEr's description and the writing of Chuang Tzu agree on the futility and foolishness of hating death.

For the next comparisons I would like to shift the emphasis to life rather than death. Chuang Tzu had much to say on how one should live according to the Tao, or Way. The following passage is a good overview of Chuang Tzu's philosophy:

Is there such a thing as supreme happiness in the world or isn't there? Is there some way to keep yourself alive or isn't there? What to do, what to rely on, what to avoid, what to stick by, what to follow, what to leave alone, what to find happiness in, what to hate?

This is what the world honors: wealth, eminence, long life, a good name. This is what the world finds happiness in: a life of ease, rich food, fine clothes, beautiful sights, sweet sounds. This is what it looks down on: poverty, meanness, early death, a bad name. This is what it finds bitter: a life that knows no rest, a mouth that gets no rich food, no fine clothes for the body, no beautiful sights for the eye, no sweet sounds for the ear.

People who can't get these things fret a great deal and are afraidthis is a stupid way to treat the body. People who are rich wear themselves out rushing around on business, piling up more wealth than they could ever use-this is a superficial way to treat the body. People who are eminent spend night and day scheming and wondering if they are doing right -this is a shoddy way to treat the body. Man lives his life in company with worry, and if he lives a long while, till he's dull and doddering, then he has spent that much time worrying instead of dying, a bitter lot indeed! This is a callous way to treat the body. (Watson, 1964. p. 111)

The above passage makes clear that Chuang Tzu did not value material possession of any kind. Many NDErs also reflect this value change after their experiences:

Material things ... have completely faded into the background; material things aren't important. (Ring, 1984, p. 133)

Oh, I liked materialism and went after it, but my values before were a lovely home and the community where I felt status.... Now my values are my smile! (Ring, 1984. p. 133)

The next comparison emphasizes nonattachment. Chuang Tzu described the True Man, or Perfect Man:

The True man of ancient times knew nothing of loving life, knew nothing of hating death. He emerged without delight; he went back in 
without a fuss. He came briskly, he went briskly, and that was all. He didn't forget where he began; he didn't try to find out where he would end. He received something and took pleasure in it; he forgot about it and handed it back again. This is what I call not using the mind to repel the Way, not using man to help out Heaven. This is what I call the True Man, (Watson, 1964, p. 74)

Notice that Chuang Tzu's True Man receives something, takes pleasure in it, and most importantly, forgets about it. Kenneth Ring made a similar observation concerning NDErs:

The correct understanding here is best expressed, I think, by saying that while NDErs, like the rest of us, enjoy their possessions, they are not particularly attached to them. They certainly don't live for them. They are there and they have their uses but in the hierarchy of NDE values, they are not of great worth. Matter is not what matters. (Ring, 1984, p. 133)

Chuang Tzu also urged people to give up the illusion of fame and reputation in order to gain a new freedom:

The whole world could praise Sung Jung-tzu and it wouldn't make him exert himself; the whole world could condemn him and it wouldn't make him mope. He drew a clear line between the internal and the external, and recognized the boundaries of true glory and disgrace. But that was all. As far as the world went, he didn't fret and worry, but there was still ground he left unturned. (Watson, 1964, pp. 25-26)

Some NDErs express a similar freedom in which they no longer are concerned about impressing others:

I think I used to be a very superficial person, always breaking my butt to please or to be accepted or to be liked. Now I just don't give a damn anymore. It's really a delicious feeling. (Ring, 1984, p. 130)

(Before) I was insecure, always. . . . [Now] if somebody doesn't like me, I don't fret about it. (Ring, 1984, p. 130)

Chuang Tzu also urged us to "stop and smell the roses":

Once a man receives this fixed bodily form, he holds on to it, waiting for the end. Sometimes clashing with things, sometimes bending before them, he runs his course like a galloping steed, and nothing can stop him. Is he not pathetic? Sweating and laboring to the end of his days and never seeing his accomplishment, utterly exhausting him- 
self and never knowing where to look for rest-can you help pitying him? I'm not dead yet! he says, but what good is that? His body decays, his mind follows it-can you deny that this is a great sorrow? Man's life has always been a muddle like this. How could I be the only muddled one, and other men not muddled? (Watson, 1964, p. 33)

NDErs also realize the futility of getting too caught up in worldly affairs: the following quotations from NDErs stress the beauty of life and living in the present moment.

This experience has really changed me and my whole attitude toward life. ... I appreciate the beauty of this life. (Ring, 1984. p. 123)

I have a fierce desire to live every wonderful moment of as many days as I can manage to be gifted with. . . My life is unquestionably even richer than before for having had the near-death experience. (Ring, 1984, p. 123)

Another thing that [the NDE] did for me was to give me the information that all you have to do to have a life of great interest . . . is simply to stay in the present moment.... If you stay there, you will live in eternity, I believe. (Ring, 1984, p. 124)

Comparing the next passages, we find that both Chuang Tzu and the NDEr emphasize inaction, and find a power and peace in stillness:

What ordinary people do and what they find happiness in-I don't know whether such happiness is in the end really happiness or not. I look at what ordinary people find happiness in, what they all make a mad dash for, racing around as though they couldn't stop-they all say they're happy with it. I'm not happy with it and I'm not unhappy with it. In the end is there really happiness or isn't there?

I take inaction to be true happiness, but ordinary people think it is a bitter thing. ... The highest happiness, keeping alive-only inaction gets you close to this! (Watson, 1964, p. 112)

I also learned to sit still [afterward]; to find power in silence. . . I learned to see the physical world in a new, highly detailed way. I noticed the changing colors of lichen on tree trunks, the shape and direction of the bark's twists. I sat by a pond and watched a reed blowing in the wind; watched the iridescently red or electrically blue damsel flies' flashing, dazzling flight. (Ring, 1984. p. 125)

The next passage from Chuang Tzu suggests an underlying purpose in life. 
How pitiful the men of the world, who think that simply nourishing the body is enough to preserve life! Then why is what the world does worth doing? It may not be worth doing, and yet it cannot be left undone-this is unavoidable. (Watson, 1964, p. 118)

Many NDErs also say their experience gave them a feeling of purpose or calling:

I think we all have had this experience for a reason. Because there is something we must do [said with emphasis]. We were given a special calling. I truly believe it's like a calling. . . . I think God knows what He's doing and we don't, so the gift is accepted without any question. But there is a purpose for us and if you want to know why, I think it's because God has called you to do something and you have to grow as a person. (Ring, 1984. p. 136)

The following passage concerns the surrender to a higher power, much like a calling or purpose, or as Chuang Tzu wrote, letting go in the Way (Wu-Wei).

Life, death, preservation, loss, failure, success, poverty, riches, worthiness, unworthiness, slander, fame, hunger, thirst, cold, heat-these are the alternations of the world, the workings of fate. Day and night they change place before us and wisdom cannot spy out their source. Therefore, they should not be enough to destroy your harmony; they should not be allowed to enter the storehouse of spirit. If you can harmonize and delight in them, master them and never be at a loss for joy, if you can do this day and night without break and make it be spring with everything, mingling with all and creating the moment within your own mind-this is what I call being whole in power. (Watson, 1964. p. 70)

The following NDEr speaks of becoming free of material possessions; note the similarity to the Taoist concept of Wu-Wei:

Before I was living for material things. ... Before I was conscious of only me, what I had, what I wanted. ... I have gradually sloughed off the desires to have and to hold earthly possessions, material possessions to any great degree. I don't worry about tomorrow . . . because I know that the Lord will take care of me. (Ring, 1984,. p. 144)

My final comparisons continue the same theme, rising above a concern with material things. Chuang Tzu tried to make us realize that we are "one with everything." 
How much more, then, is possible for a man who governs Heaven and earth, stores up the ten thousand things, lets the six parts of his body be only dwelling, makes ornaments of his ears and eyes, unifies the knowledge of what he knows, and in his mind never tastes death. He will soon choose the day and ascend far off. Men may become his followers, but how could he be willing to bother himself about things? (Watson, 1964, p. 65)

Likewise, the NDEr quoted below has "grown to really know what love is in a universal sense." This is what Chuang Tzu meant by "storing up the ten thousand things": giving up on one's own ego and attaining a level of higher consciousness where the distinctions between things, especially people, are lost:

I went from a person who was selfish, empty, vain, completely vain, frightened of life, of living, of death, of anything and everything to ... a real sense of freedom in my inmost being, a complete sense of knowledge with God; I've grown to really know what love is in a universal sense, and I'm still growing in that area. . . . As I look back on [the NDE], it seems to me that the reason for this happening was for God to come into my life because I wouldn't let Him come in any other way.... I feel now that God is first in my life. . . In all reality, what this has done also is give me the freedom to be myself, to find myself . . . to be what God wants me to be. (Ring, 1984, p. 144)

Chuang Tzu made many references to attaining the ten thousand things; there are many parallels in this to the attainment of global consciousness.

Once a person reaches such a level of higher consciousness through an NDE or any other process, he or she will necessarily have views and beliefs that are parallel or similar to Chuang Tzu. Attaining this cosmic consciousness, in which there is an awakening from the dream of life for at least a little while, is the core of the NDEr's experience. The following passage by Chuang Tzu explains his feeling that life is a dream:

He who dreams of drinking wine may weep when morning comes; he who dreams of weeping may in the morning go off to hunt. While he is dreaming he does not know it is a dream, and in his dream he may even try to interpret a dream. Only after he wakes does he know it was a dream. And someday there will be a great awakening when we know that this is all a great dream. Yet the stupid believe they are awake, busily and brightly assuming they understand things, calling this man ruler, that one herdsman - how dense! Confucius and you are both dreaming! And when I say you are dreaming, I am dreaming too. Words like these will be labeled the Supreme Swindle. Yet, after ten 
thousand generations, a great sage may appear who will know their meaning, and it will still be as though he appeared with astonishing speed. (Watson, 1964, p. 43)

Chuang Tzu and NDErs are similar in that they have realized that our life is like a dream. The near-death experience is a kind of awakening, in which NDErs realize firsthand that there is no death and that they are one with all others. The value changes in NDErs are a result of this awakening. Since life is only a dream, NDErs become less attached to holding onto it, and higher values of love and knowledge take the place of material possessions. These higher values of love and knowledge are byproducts of the NDErs' new calling and purpose. In a sense, they awaken from their old lives to discover a new higher purpose of what Chuang Tzu called the Way.

\section{References}

Moody, R. A. Jr. (1975). Life after life. Covington, GA: Mockingbird.

Ring, K. (1984). Heading toward omega. New York, NY: William Morrow.

Watson, B. (1964). Chuang Tzu. New York, NY: Columbia University Press. 